\title{
A Soil Health Card (SHC) for soil quality monitoring of agricultural lands in south-eastern coastal region of Bangladesh
}

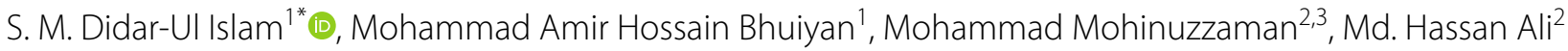 \\ and Shaila Rahman Moon²
}

\begin{abstract}
Background: The present study introduces an alternate tool of laboratory analysis named Soil Health Card (SHC) for soil quality monitoring and routine field observations by farmers.

Results: Different physicochemical and nutrient contents of soil, i.e. pH, electric conductivity, soil organic matter, organic carbon, total nitrogen, phosphorous, sulfur and boron were assessed by laboratory analysis collected from the different fields of Noakhali district of Bangladesh. These parameters were scored according to the soil fertility standards according to Bangladesh Agriculture Research Council. Results found that, the soil quality of all the studied fields are medium category. Again, a SHC was prepared using soil structure, subsurface compaction, aggregate stability, status of ground cover, soil smell, soil pH, color, organic matter content, drainage capacity, diversity of micro-life, earthworm contents, infiltration rate, soil aeration, crop coverage and leaf color. The result of SHC is interestingly similar to the laboratory experiment results.
\end{abstract}

Conclusions: Analyzing these two methods it was found that, the SHC is truly representative, much convenient, precise, coast effective and easily understandable to the marginal farmers. However, SHC can be an alternative to farmer for sustainable farm management.

Keywords: Agricultural land, Bangladesh, Nutrient, Soil Health Card (SHC), Soil quality

\section{Background}

Bangladesh is predominantly an agro-based country. The total cropped area is 15.085 million hectares with crop production of 37.266 million metric tons (Karlen et al. 1999; DAE-AIS 2013). Agricultural sector provides $29 \%$ of the country's Gross Domestic Production (GDP) and generates employment for $63 \%$ of the total labor force both directly and indirectly (Khan et al. 2015). Bangladesh has made a remarkable progress in the last three decades achieving self-sufficiency in food grains production due to substantial intensification of cropping, practicing high yield crop varieties, and expansion of irrigated areas and increased use of chemical fertilizers. Among

\footnotetext{
${ }^{*}$ Correspondence: smdidarulislamju@gmail.com

1 Department of Environmental Sciences, Jahangirnagar University, Dhaka 1342, Bangladesh

Full list of author information is available at the end of the article
}

the factors mentioned above, fertilizers contribute $50 \%$ of the total production (FRG 2012). But recently, declining or stagnation of major crop yields have been recorded due to cumulative effects of many soil-related constraints and climatic risks, i.e. depletion of soil organic matter, imbalanced use of fertilizers, nutrient mining, degradation of soil physical and chemical properties, erratic rainfall, temperature rise, droughts, floods, soil salinity, water salinity, tidal surges, water-logging, cyclone, scanty use of bio and organic fertilizers and poor management practices (Miah 2010; Sangral 2015; Islam et al. 2015; Islam and Bhuiyan 2016). Mineral N-P-K fertilizer additions, supported with the pesticides and herbicides leads to degrade the humic portion of soil, which gradually destroying the plant nutrition and soil fertility (Pettit 2006; Rahman et al. 2012). Moreover, excess use and exposure of pesticides and herbicides, leads to 
environmental pollution and do harm human health a lot (Chitra et al. 2006). The overuse of chemical fertilizers and poor soil management contributed to surface and groundwater pollution in many regions in the developing countries which may cause human health hazard (Magdoff and Harold 2009). The overall degradation or pollution processes lead to decrease soil health of a farm soil.

Soil health is defined as an integrative property that reflects the level of ecosystem services, and the capacity of agricultural production (Kibble-white et al. 2008). Soil quality is considered as the main factor determining the total soil functions and health. For example, organic residue and root biomass from crop plants feed soil organisms and contribute to soil organic matter which in turn develops soil structure (Wander 2004). Both air and water occupy the pore spaces created within and between soil aggregates that means the clusters of sand, silt and clay particles which bound together by particle surface chemistry and microbial and plant exudates (Gugino et al. 2009). Thus if any major function disrupts then the total soil consequently will be affected. Poor soil quality usually provides a poor production of crops (Franzlubbers and Haney 2006; Idowu et al. 2008). Soil quality enrichment improves the capacity of a soil function within ecosystem and land use boundaries to sustain productivity, maintain environmental quality, and promote plant and animal health (Doran and Parkin 1994; Karlen et al. 1997).

The farmers of Bangladesh are not financially solvent. So monitoring of soil quality using a cost effective and convenient tool is a crying need to adopt sustainable development in agricultural practices nowadays for marginal farmers. Previously many authors, i.e. Romaniuk et al. (2014), Gong et al. (2015), Raiesi and Kabiri (2016), and Vasu et al. (2016) create a broader linkage between soil quality and sustainability using soil quality indexing approach fruitfully. Among them, soil quality test kits (Sarrantonio et al. 1996; SQTKG 1999), farmer-based scorecards (Romig et al. 1996) and soil resource management programs (Walter et al. 1997) focus on farmerbased evaluations regarding soil management practices and their effects on soil. Gugino et al. (2009) found that, soil quality assessment using different indicator is much easier for soil health monitoring of agricultural lands. This technique provides an aim to evaluate the tillage systems, detect and improve problem of fields, make baseline assessments of new ground or for precision agriculture systems and demonstrate that soil quality under current farming practices. As, laboratory analysis of soil is expensive, more time consuming and not convenient for marginal farmers so the present study aims to introduce an alternate method name SHC and its application for soil monitoring in agricultural lands using different indicators. The study also intended to compare SHC with laboratory analysis, its significance and develop it for farmer's usages for sustainable land management.

\section{Methods \\ Study area}

Noakhali district is located at the south-eastern coastal region of Bangladesh. Geographically it lies between $22^{\circ} 06^{\prime}$ and $23^{\circ} 17^{\prime}$ North latitudes and between $90^{\circ} 38^{\prime}$ and $91^{\circ} 35^{\prime}$ East longitude (Fig. 1). The total area of Noakhali is $3685.87 \mathrm{Sq} . \mathrm{km}$ and the population is 310808.3 million (BBS 2011). The annual average temperature of this district ranges from a maximum of $34.3{ }^{\circ} \mathrm{C}$ to a minimum of $14.4{ }^{\circ} \mathrm{C}$ and average annual rainfall is $3302 \mathrm{~mm}$. The area represents an extensive flat, coastal and deltaic land, located on the tidal floodplain of the Meghna River delta, characterized by flat land and low relief. The area is influenced by diurnal tidal cycles and the tidal fluctuations vary depending on seasons, being pronounced during the monsoon season. The economy of Noakhali is depends on agriculture and they produce varieties of crops, namely local and hybrid rice, wheat, vegetables, spices, cash crops, pulses, betel leaves, peanuts, onion, oil seeds and others. $30 \%$ of the regional GDP comes from agriculture with $45 \%$ of the population employed in the sector (BBS 2011). Noakhali, being exposed to the Bay of Bengal is prone to multiple hazards. Cyclones are frequently occurring disasters, which hit the coastal villages every year. Sometimes, cyclones accompanied by tidal surge inundate the very remote coastal areas of the district and cause massive destruction. Along with these, annual flooding due to excessive rainfall and poor drainage systems has recently been devastating (Banglapedia 2016).

\section{Sampling and laboratory analysis}

Soil samples were collected during January 2016 from ten fields of the study area (Fig. 1) before land preparation from plough-depth maintaining the ideal soil sampling protocol (Gupta 2000). Five samples were collected from each fields and analyzed for $\mathrm{pH}, \mathrm{EC}, \mathrm{OC}, \mathrm{OM}, \mathrm{TN}, \mathrm{P}, \mathrm{K}$, $\mathrm{S}$ and $\mathrm{B}$ in regional laboratory of Soil Resource Development Institute (SRDI), Noakhali. Soil pH was determined with the help of a glass electrode $\mathrm{pH}$ meter; the soil-water ratio was maintained as 1:2.5 according to Jackson (1962). To measure electric conductivity, EC1:1 method was used (Smith and Doran 1996). Organic carbon in soil sample was determined volumetrically by wet oxidation method of Walkley and Black (1934). The underlying principle is to oxidize the organic matter with an excess of $1 \mathrm{~N} \mathrm{~K}_{2} \mathrm{Cr}_{2} \mathrm{O}_{7}$ in presence of conc. $\mathrm{H}_{2} \mathrm{SO}_{4}$ and to titrate the residual $\mathrm{K}_{2} \mathrm{Cr}_{2} \mathrm{O}_{7}$ solution with $1 \mathrm{~N}$ $\mathrm{NH}_{4} \mathrm{FeSO}_{4}$. The amount of soil organic matter was calculated by multiplying the value of organic carbon with 


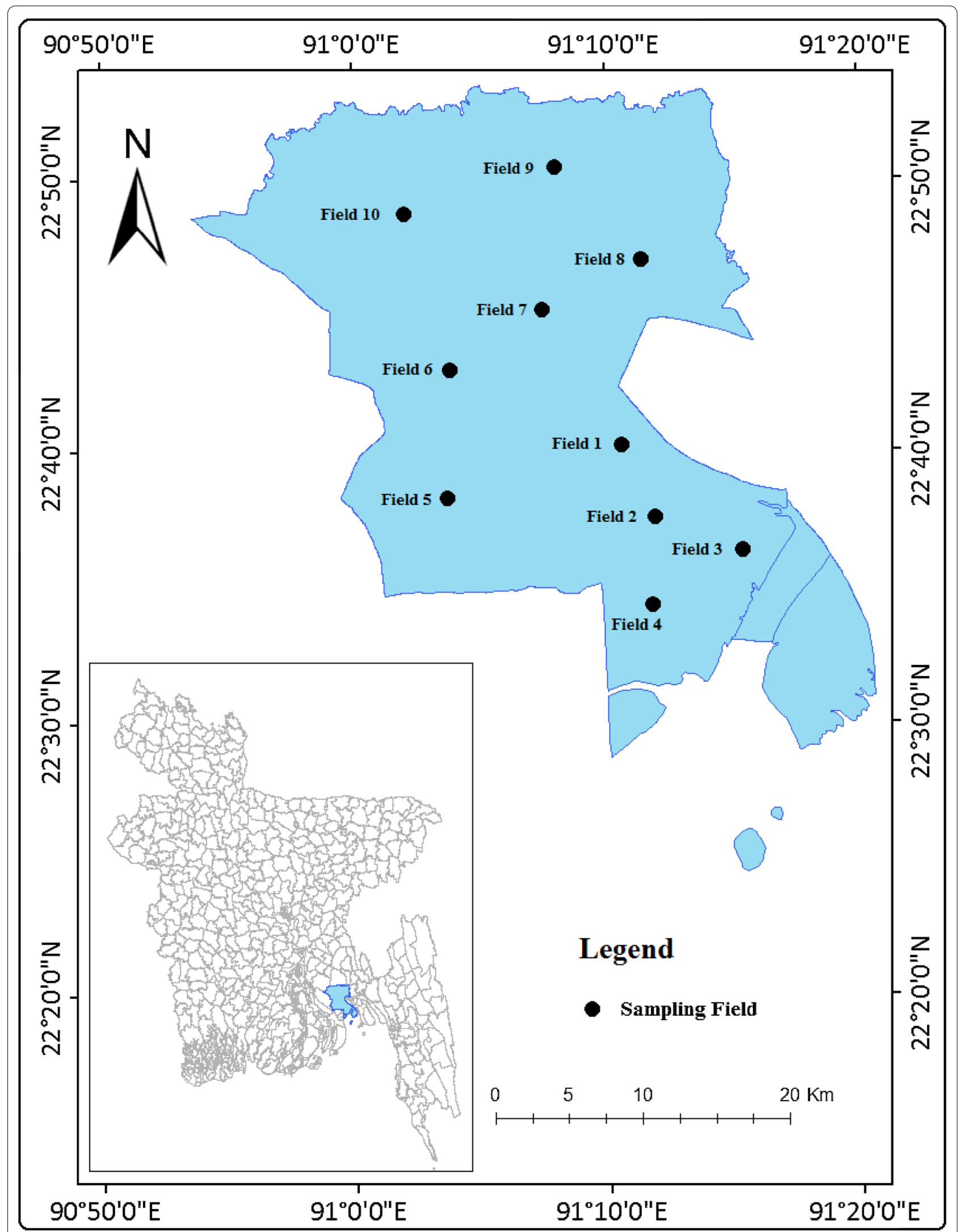

Fig. 1 Map of study area showing the sampling fields 
the Van Bemmelen factor, 1.724 (Piper 1950). The total nitrogen in the soil was determined by Kjeldahl method by digesting soil sample at $390{ }^{\circ} \mathrm{C}$ in a digestion tube with $5 \mathrm{ml} 98 \%$ conc. $\mathrm{H}_{2} \mathrm{SO}_{4}$ and 1.0 g catalyst mixture $\left(\mathrm{K}_{2} \mathrm{SO}_{4}: \mathrm{CuSO}_{4} \cdot 5 \mathrm{H}_{2} \mathrm{O}=10: 1\right)$ by a digestion unit (Page et al. 1982).

Available phosphorus was extracted from the soil by shaking with $0.03 \mathrm{M} \mathrm{NH}_{4} \mathrm{~F}-0.025 \mathrm{M} \mathrm{HCl}$ solution at $\mathrm{pH}<7.0$ following the method of Bray and Kurtz (1945). The phosphorus in the extract was then determined by developing a color using ammonium molybdate-ascorbic acid solution to the extract. The intensity of blue color was measured at $890 \mathrm{~nm}$ wave length in spectrophotometer and available $P$ was calculated with the help of standard curve. Potassium was determined by using flame photometer (Black et al. 1965).

Available S content of soil was determined by extracting the soil with $\mathrm{S}$ extracting solution. The extractable sulphur content was determined by developing turbidity by adding acid seed solution $\left[150 \mathrm{ml}\right.$ conc. $\mathrm{HNO}_{3}, 550 \mathrm{ml}$ glacial acetic acid and $7 \mathrm{ml}$ sulphur stock solution-1 (1000 mg/L S) was mixed added water to volume $2 \mathrm{~L}$ ] and turbidimetric reagent $20 \mathrm{~g}$ polyvinylpyrrolidone and $300 \mathrm{~g} \mathrm{BaCl}_{2} \cdot 2 \mathrm{H}_{2} \mathrm{O}$ up to $2 \mathrm{~L}$ volume with distilled water]. The intensity of turbidity was measured by spectrophotometer at $535 \mathrm{~nm}$ wave length following the extractionturbidity method described by Fox et al. (1964). For measuring boron, at first nitrogen digester should turned on and was adjusted it to $150{ }^{\circ} \mathrm{C}$. Then soil was digested with $0.01 \mathrm{M} \mathrm{CaCl}_{2}$ solution in the ratio 1:2 into clean and dry digestion tubes with glass stopper in each. After first bubble, the temperature setting was reduced to $110{ }^{\circ} \mathrm{C}$ and boiled for exactly $5 \mathrm{~min}$ from the time was start. The digester was turned and placed the tubes in a vessel with cold water for $15 \mathrm{~min}$ and filtered on a dry filter into a dry plastic bottle and then Transferred $2.0 \mathrm{ml}$ undiluted filtrate into another dry plastic bottle, added $4 \mathrm{ml}$ buffer solution and $4 \mathrm{ml}$ Azomethyl-H reagent and mixed. After $30 \mathrm{~min}$ the absorbance was measured at $420 \mathrm{~nm}$ on a spectrophotometer and calculated by using a standard curve (Petersen 2013).

\section{Field observation for SHC preparation}

In 2002 a group of Northern Rivers Region farmers develop a soil health monitoring tool named Northern Rivers Soil Health Card (NRSHC), based on United States Department of Agriculture (USDA) format. A major value of the exercise was the farmer involvement that allowed the card to be customized to fit the needs of the individual using it. It is simple and effective extension tool for soil quality monitoring using simple rating system that people can use to evaluate and monitor soil health or compare practice effects on soil health. In this process farmer participation was taken, which has facilitated engagement and increased awareness of soil health issues and enabled farmers to self diagnose and solve their own problems (Lobry de Bryun and Abbey 2003). To prepare SHC, soil health indicator of NRSHC method was used in this study. To prepare SHC ground cover percentage were assess using coat hanger quadrate, which put into the ground at random manner and estimated the proportion of bare soil within the frame and subtracted from $100 \%$ (NRSHC 2002). For the infiltration test, the infiltrometer tube was pushed to the soil up to $1-2 \mathrm{~cm}$ into the soil, avoiding cracks and other holes in the ground. The tube was filled with water and the time was recorded by stopwatch how far the water level had fallen up to $5 \mathrm{~min}$. The rate of infiltration then counted by ratio of water level decrease and time elapsed to infiltrate the total water (NRSHC 2002). For counting the diversity of macro life, the coat hanger quadrate was put on the ground at the undisturbed area and avoid the movement of varieties of soil animals such as ants, beetles, spiders, slaters, millipedes, mites and others were noted (NRSHC 2002). To measure the root development $15 \mathrm{~cm}$ square hole of soil surface was cut from the ground. The soil was lifted out as one block placing on the plastic sheet for observing the plant root and recorded on the card (NRSHC 2002). For observing soil structure, a handful of soil away from the surface of the block was dug up. The size and arrangement of the soil 'aggregate or crumbs' were examined under firm finger pressure (NRSHC 2002). To examine the crumbs stability 3 or 4 pea-sized soil crumbs were taken from $5 \mathrm{~cm}$ depth for avoiding small stones. The crumbs were merged into $125 \mathrm{ml}$ water at a small wide mouthed jar for $1 \mathrm{~min}$. After $1 \mathrm{~min}$ the crumbs were broke apart or stay intact (NRSHC 2002). To count the earthworm content, the total soil block was broken into small crumbs for observation if any worms were found into a jar. Any worm that was longer than $25 \mathrm{~mm}$ recorded on the sheet and let them return to the hole (NRSHC 2002). To measure soil pH, two small samples of soil were taken from the side of the hole-one from $5 \mathrm{~cm}$ and another from $15 \mathrm{~cm}$ depth. These samples were color matched with $\mathrm{pH}$ kit. Leaf color and plant growth crop, trees or pasture at the soil test site were observed visually (NRSHC 2002). Organic matter was determined in two soil sample collected from the surface (topsoil) and $25 \mathrm{~mm}$ (subsoil) depth. The soil color from the two depths was compared. When the surface color similar to the subsoil color the smell of the soil sample was taken for differentiate. A sweet earthy smell indicates the soil was rich in organic matter (SQCDG 1999). For the seedling emergence about 100 sections of seeded rows were measured with tape and the height of several plants within the row was measured randomly (PNSQCG 2004). Drainage 
capacity was examined from the farmers interview that how many days rainwater needs to erase from the field totally after a heavy rain such $2,3,5$ or 7 days. Below 1 day it prefers good, 2-3 days indicates the medium and 5-7 days indicates the poor drainage capacity of the field (NRSHC 2002).

\section{Data interpretation and analysis}

To evaluate soil quality, measured soil parameters in laboratory are scored according to Bangladesh Agricultural Research Council (BARC) soil fertility standard (FRG 2012). To prepare SHC, several important soil health indicators (Table 1) based on farmer's practical experience and knowledge of local natural resources were determined. The soil characteristics were classified in terms these indicators.

\section{Results and discussion}

Soil quality determination using laboratory assessment

The value of measured soil parameters and nutrients content in the studied fields are given in Table 2 with assumption based on FRG (2012). Soil pH is a measure of its acidity or alkalinity and is an important property because of its influence on the supply of nutrients (cations and anions) to plants, the chemical behavior of toxic elements and the activity of microorganisms. The $\mathrm{pH}$ of soil varied from 6.94 to 8.22 with a mean value of 7.67 which is slightly alkaline. On the cropping system, a change in $\mathrm{pH}$ may have effects on soil quality. Important factors affecting soil $\mathrm{pH}$ including; parent material, alkali salts, drainage system, weathering-erosion, types of fertilizers, proximity to metal ore smelters, and residual base saturation capacity (Arshad and Coen 1992).

Soil electrical conductivity (EC) is a measurement that correlates soil properties that affect crop productivity including soil texture, cation exchange capacity, drainage conditions, organic matter level, salinity and sub-soil characteristics. On the other hand, the electrical conductivity of soils varies depending on the amount of soil moisture. Generally EC has good relationship with soil particle size and texture (Grisso et al. 2009). The EC of the samples ranges from 0.79 to $6.67 \mathrm{dS} / \mathrm{m}$ with a mean of $2.75 \mathrm{dS} / \mathrm{m}$ (Table 2).

Organic matter $(\mathrm{OM})$, an important properties derived from the decomposition of plants and animals. A wide variety of organic carbon in soils range from freshly deposited litter, i.e. leaves, twigs, branches, etc. to highly decomposed forms, i.e. humus (Schumacher 2002). OM defines the total carbon storage, fertility and stability of a particular soil mass (Brady and Weil 2005). Potential benefits of increased microbial biomass and their activities includes; increased soil aggregate formation and stability, enhanced plant litter decomposition, increased nutrient cycling and transformations, slow-release storage of organic nutrients, and pathogen control (Lagomarsino et al. 2009; Nautiyal et al. 2010). Organic matter contents of the studied field were found $0.34-2.54 \%$ which indicates low to medium percentage of OM.

Soil nutrients are the indicator of soil total productivity and agrochemical quality. Their levels and transformations are critical to soil health (Kibble-white et al. 2008). Organic $C$ and $N$ controls soils microbial catalytic potential and indicates the early warming of management effect on organic matter (Brady and Weil 2005). Soil organic $\mathrm{C}$ and total $\mathrm{N}$ of the studied samples varied from 0.20 to $1.48 \%$ and 0.02 to $1.12 \%$, respectively which are very low.

$\mathrm{P}$ and $\mathrm{K}$ are the most essential nutrients for plant growth. P range from 1.75 to $36.52 \mu \mathrm{g} / \mathrm{g}$ with a mean value of $8.21 \mu \mathrm{g} / \mathrm{g}$. Except one sampling field all the sampling fields contain very low phosphorus. Potassium (K) concentrations from 0.15 to $0.33 \mathrm{meq} / 100 \mathrm{~g}$ fall into low to medium range according to the FRG (2012). S is less available but important for soil structure and plant growth (Northern Rivers Soil Health Card-Perennial Horticulture (NRSHCPH) 2010). S content varied from 18.75 to $262.95 \mu \mathrm{g} / \mathrm{g}$, with a mean value of $138.60 \mu \mathrm{g} / \mathrm{g}$ indicates high range. $\mathrm{B}$ is also substantial micronutrient that occurs in very high levels compared to optimum $(1.15-3.04 \mu \mathrm{g} / \mathrm{g})$. From the Bangladesh Agricultural Research Council (BARC) soil fertility standard (FRG 2012) it is found that soil quality is medium (Table 3).

\section{Physical observation and preparing Soil Health Card (SHC)}

The SHC is used to evaluate the status of soil quality and their changes in soil that are affected by field management. A single card covers a specific eco-region characterized by comparable natural resources and farming conditions (USDA-NRCS 1998). The card is developed to assess the soil health through field observations of soil physical, chemical and biological properties (Romig et al. 1996). It provides a qualitative assessment of soil health, and evaluates ratings that do not represent an absolute measure. For farm management soil quality and soil health is recommended to assist farmers to evaluate the effects of their management decisions on soil productivity. The purpose of SHC is not only useful for comparing soil types with one-another, rather to assess each soil's ability to function within its capabilities and outer limitations. Brejda and Moorman (2001) stated that soil quality cannot be measured without some sensitive indicators. A soil quality indicator is a measurable soil property that affects the capacity of a soil to perform a specified function. For the evaluation of soil quality parameters it is desirable to select indicators that are directly related to soil quality (Wang and Gong 1998). The use of scorecards 


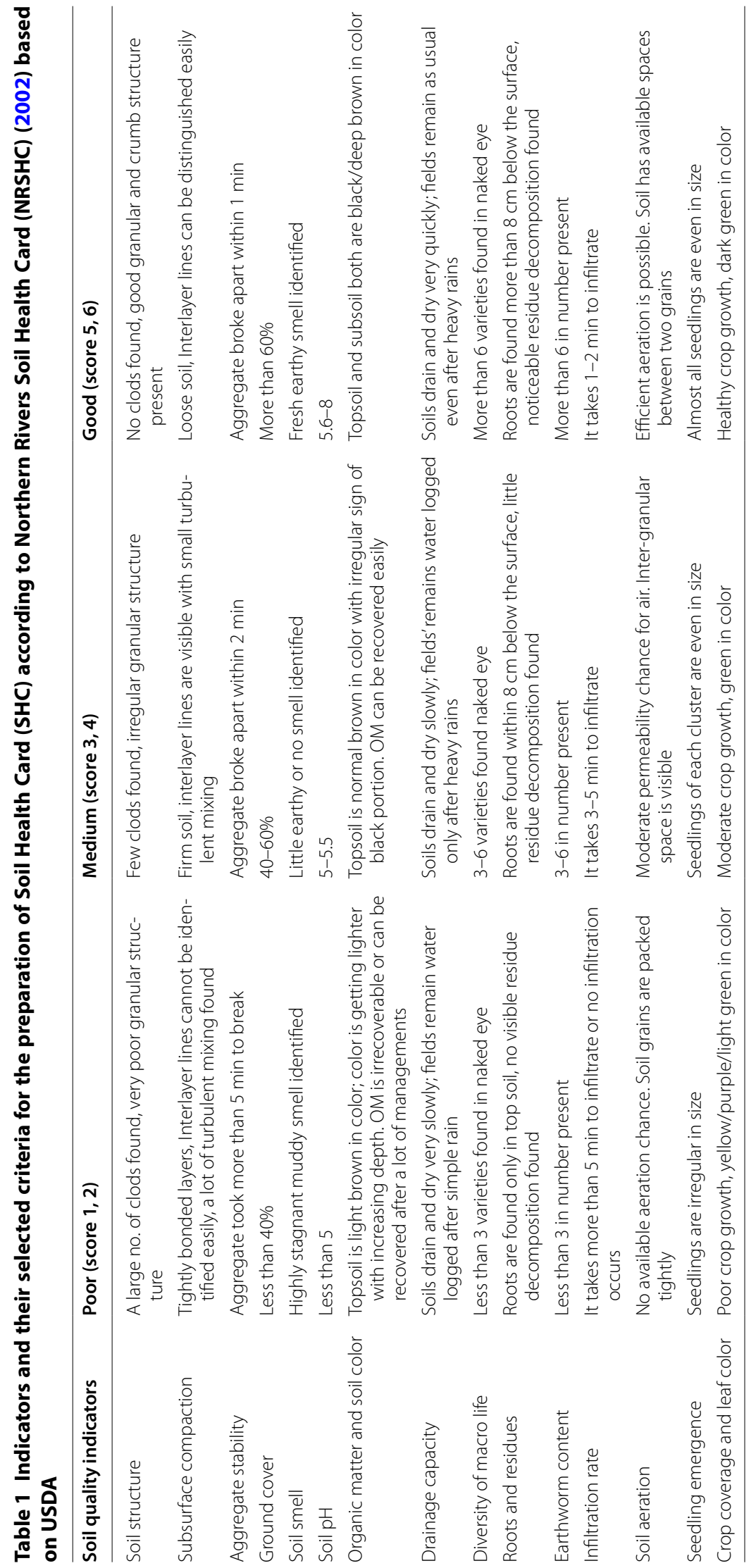


Table 2 Soil physicochemical and nutrient contents from laboratory analysis

\begin{tabular}{|c|c|c|c|c|c|c|c|c|c|}
\hline Field sample no. & $\begin{array}{l}\mathrm{pH} \\
-\end{array}$ & $\begin{array}{l}E C \\
d S / m\end{array}$ & $\begin{array}{l}\text { OM } \\
\%\end{array}$ & $\begin{array}{l}\text { OC } \\
\%\end{array}$ & $\begin{array}{l}\mathrm{TN} \\
\%\end{array}$ & $\begin{array}{l}P \\
\mu g / g\end{array}$ & $\begin{array}{l}\mathrm{K} \\
\mathrm{meq} / 100 \mathrm{~g}\end{array}$ & $\begin{array}{l}S \\
\mu g / g\end{array}$ & $\begin{array}{l}\text { B } \\
\mu \mathrm{g} / \mathrm{g}\end{array}$ \\
\hline \multirow{2}{*}{$\begin{array}{l}\text { Field-1 } \\
n=5\end{array}$} & 7.86 & 1.02 & 1.17 & 0.68 & 0.06 & 5.49 & 0.26 & 56.81 & 1.17 \\
\hline & SA & NS & L & & $V L$ & $\mathrm{VL}$ & M/Opt & VH & $\mathrm{VH}$ \\
\hline \multirow{2}{*}{$\begin{array}{l}\text { Field-2 } \\
n=5\end{array}$} & 8.22 & 0.79 & 0.34 & 0.20 & 0.02 & 5.73 & 0.32 & 18.75 & 1.15 \\
\hline & SA & NS & $\mathrm{VL}$ & & $V L$ & VL & $\mathrm{Opt} / \mathrm{H}$ & M & $\mathrm{VH}$ \\
\hline \multirow{2}{*}{$\begin{array}{l}\text { Field-3 } \\
n=5\end{array}$} & 8.00 & 4.33 & 1.17 & 0.68 & 0.06 & 6.91 & 0.30 & 254.93 & 1.69 \\
\hline & SA & SS & L & & $V L$ & $V L / L$ & Opt & $\mathrm{VH}$ & $\mathrm{VH}$ \\
\hline \multirow{2}{*}{$\begin{array}{l}\text { Field-4 } \\
n=5\end{array}$} & 7.86 & 6.67 & 0.83 & 0.48 & 0.04 & 36.52 & 0.30 & 144.86 & 2.27 \\
\hline & SA & SS & $\mathrm{VL}$ & & $V L$ & $\mathrm{H} / \mathrm{VH}$ & Opt & $\mathrm{VH}$ & $\mathrm{VH}$ \\
\hline \multirow{2}{*}{$\begin{array}{l}\text { Field-5 } \\
n=5\end{array}$} & 7.98 & 1.27 & 2.27 & 1.32 & 0.11 & 10.18 & 0.33 & 80.43 & 1.78 \\
\hline & SA & NS & M & & L & L & Opt/H & $\mathrm{VH}$ & $\mathrm{VH}$ \\
\hline \multirow{2}{*}{$\begin{array}{l}\text { Field- } 6 \\
n=5\end{array}$} & 7.92 & 1.52 & 1.58 & 0.92 & 0.08 & 6.54 & 0.22 & 78.51 & 1.83 \\
\hline & SA & NS & L & & VL & $V L / L$ & M & VH & $\mathrm{VH}$ \\
\hline \multirow{2}{*}{$\begin{array}{l}\text { Field-7 } \\
n=5\end{array}$} & 7.45 & 6.08 & 2.41 & 1.40 & 0.12 & 1.75 & 0.19 & 262.95 & 2.39 \\
\hline & SA & SS & M & & L & $V L$ & M & $\mathrm{VH}$ & $\mathrm{VH}$ \\
\hline \multirow{2}{*}{$\begin{array}{l}\text { Field-8 } \\
n=5\end{array}$} & 6.94 & 2.19 & 2.54 & 1.48 & 0.12 & 2.95 & 0.17 & 202.25 & 2.41 \\
\hline & $\mathrm{Nu}$ & FS & M & & L & $V L$ & L/M & $\mathrm{VH}$ & $\mathrm{VH}$ \\
\hline \multirow{2}{*}{$\begin{array}{l}\text { Field-9 } \\
n=5\end{array}$} & 7.48 & 0.94 & 1.99 & 1.16 & 0.10 & 3.35 & 0.19 & 88.26 & 2.52 \\
\hline & SA & NS & $\mathrm{M}$ & & L & $V L$ & $\mathrm{M}$ & VH & VH \\
\hline \multirow{2}{*}{$\begin{array}{l}\text { Field-10 } \\
n=5\end{array}$} & 6.96 & 2.61 & 1.79 & 1.04 & 0.09 & 2.59 & 0.15 & 198.22 & 3.04 \\
\hline & $\mathrm{Nu}$ & FS & $\mathrm{M}$ & & $V L$ & VL & L & $\mathrm{VH}$ & VH \\
\hline Max & 8.22 & 6.67 & 2.54 & 1.48 & 0.12 & 36.52 & 0.33 & 262.95 & 3.04 \\
\hline Min & 6.94 & 0.79 & 0.34 & 0.20 & 0.02 & 1.75 & 0.15 & 18.75 & 1.15 \\
\hline Mean & 7.67 & 2.75 & 1.61 & 0.94 & 0.08 & 8.21 & 0.25 & 138.60 & 2.025 \\
\hline
\end{tabular}

$S A$ slightly alkaline, Nu Neutral, $V L$ very low, $L$ low, $M$ medium, $H$ high, $V H$ very high, Opt optimum, $N S$ non saline, $F S$ few saline, SS slightly saline

for on-farm soil quality assessment is emphasized where qualitative observations of soil health are scored to obtain an overall measure of soil quality (Kinyangi 2007; Romig et al. 1996). Two primary reasons for developing scorecards were to promote an increased awareness regarding soil resources and to encourage landowners and operators to "look below ground" when they are evaluating their soil management practices (Karlen et al. 1999). The soil characteristics were classified in terms of the descriptive indicators (Table 1) which were interpreted on a graded scale in Table 4 . By scoring all the measured indicators in fields, it was found that the percentage of total score of the studied fields were 83.34, 45.24, 59.53, 50.00, $50.00,61.91,71.43,76.19,61.91$ and $50.00 \%$ respectively indicating that except Field 1, soil health quality of all the fields are medium in character (Table 4). This on-farm assessment of soil quality and health is recommended to assist farmers to evaluate the effects of their management decisions on soil productivity.

\section{Comparison among traditional and laboratory analysis}

From the scoring of studied parameters, it is found that the soil quality is medium according to laboratory analysis (Table 3). Here it should be noted that the scoring of soil chemical parameters were conducted according to Bangladesh Agricultural Research Council (BARC) fertility standard (Hassan et al. 2012), and according to the SHC soil quality of the studied fields is also medium except Field 1 (Table 4). The comparison among the two methods is presented in Fig. 2. Nevertheless it can be said that this Soil Health Card (SHC) assessment is truly representative and may be an alternative for laboratory assessment method.

\section{Benefits of using Soil Health Card (SHC)}

(a) Coasting: cost effectiveness is a major factor for determining soil quality in the field. The total cost required for the two assessment methods are presented in Table 5, and it is found that SHC preparation is much cheaper than the assessment of soil quality by laboratory analysis. So the SHC preparation technique is more cost-effective than any other conventional methods.

(b) Flexibility and time duration: to prepare SHC only field work is essential. But for the assessment of soil quality by measuring physicochemical parameters 


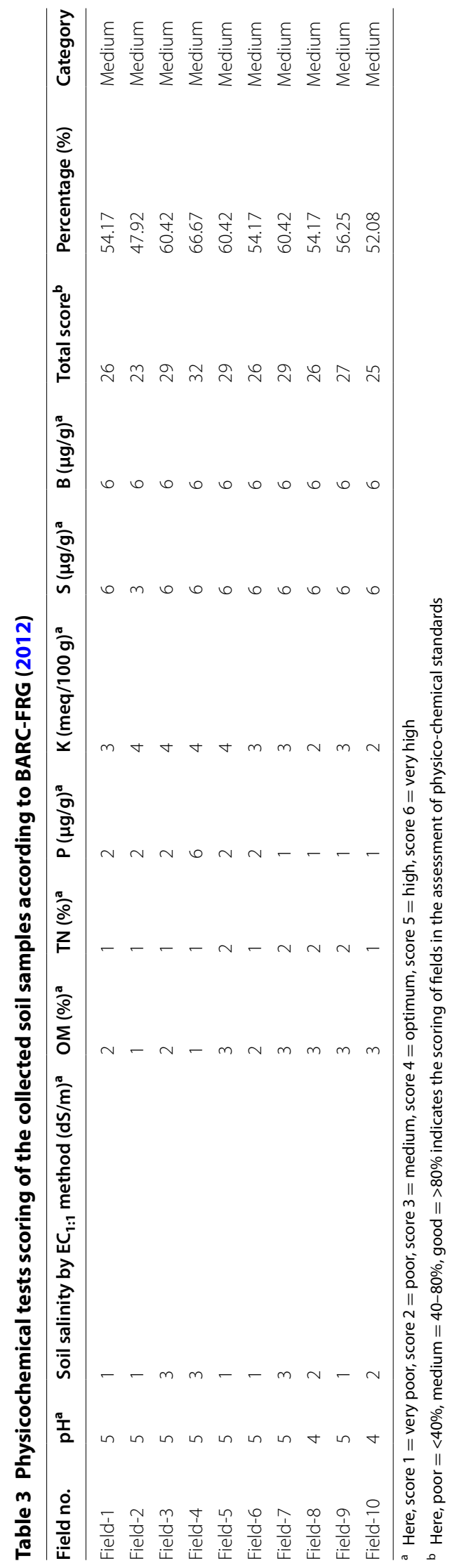




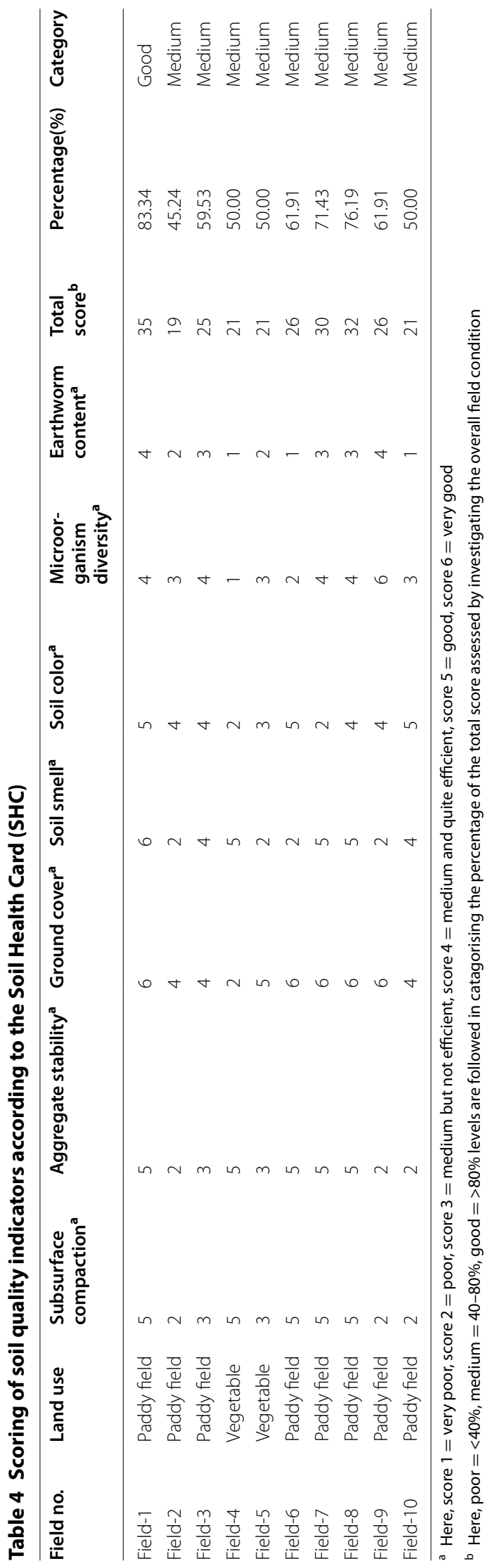




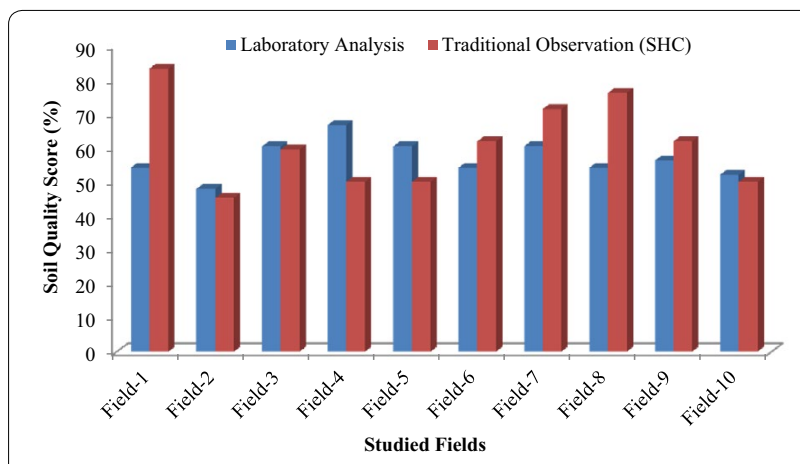

Fig. 2 Comparison between SHC and laboratory analysis test scores

Table 5 Comparison of total costing for laboratory assessment and SHC preparation

\begin{tabular}{lll}
\hline Issues & $\begin{array}{l}\text { Cost (in BDT) } \\
\text { for laboratory } \\
\text { assessment }\end{array}$ & $\begin{array}{l}\text { Cost (in BDT) } \\
\text { for SHC prepa- } \\
\text { ration }\end{array}$ \\
\hline $\begin{array}{l}\text { Transportation } \\
\begin{array}{l}\text { Field equipments total cost } \\
\text { (rent) }\end{array}\end{array}$ & 1000 & 500 \\
$\begin{array}{l}\text { Sampling bag and plastic sheet } \\
\text { Lab test (chemical) }\end{array}$ & 150 & 550 \\
$\begin{array}{l}\text { Lab test (physical) } \\
\text { Team organizations with farmers } \\
\text { and others (3 members) }\end{array}$ & N/A & N/A \\
\begin{tabular}{l} 
Total cost \\
\hline
\end{tabular} & 3900 N/A \\
\hline
\end{tabular}

one has to work both in field and laboratory. In the SHC assessment method no need to sample preparation, which saves the time. The farmers do not need to go to the soil testing office to collect their soil quality data that provides farmers comfortless. So assessment of soil quality by SHC method is much flexible time effective than another one.

\section{Conclusion}

Soil Health Card (SHC) is a qualitative assessment tool which can be easily prepared by farmers that can be effective for assessing soil health from routine field observations. It is an initiative for farmers to manage their soil for productivity and for environmental protection. In this study $\mathrm{SHC}$ was used to compare with laboratory experiment and found that, the SHC score in percentage was 83.34, 45.24, 59.53, 50.00, 50.00, 61.91, $71.43,76.19,61.91,50.00 \%$ which were very similar to the laboratory studied parameters score and the field soil quality is medium category for agricultural use. A farmer can perform a full grade of necessary field management with assistance of this card without any disturbance and long term use of this health card will provide a fruitful soil quality changing trends. This will help farmers to run a sustainable farming system that refers to a complex ecosystem with non-linear dynamics.

\begin{abstract}
Abbreviations
BARC: Bangladesh Agricultural Research Council; B: boron; EC: electric conductivity; GDP: Gross Domestic Product; $\mathrm{HCl}$ : hydrochloric acid; $\mathrm{H}_{2} \mathrm{SO}_{4}$ : sulfuric acid; $\mathrm{K}$ : potassium; $\mathrm{K}_{2} \mathrm{Cr}_{2} \mathrm{O}_{7}$ : potassium dichromate; NRSHC: Northern Rivers Soil Health Card; OC: organic carbon; P: phosphorus; SHC: Soil Health Card; OM: organic matter; S: sulfur; TN: total nitrogen; USDA: United States Department of Agriculture.
\end{abstract}

\section{Authors' contributions}

SMDI literature review, field survey, data analysis and manuscript preparation. MAHB overall management of the field survey and reviewing the manuscript. MM financial support and reviewing the manuscript. MHA field survey and laboratory analysis. SRM field survey and laboratory analysis. All authors read and approved the final manuscript.

\section{Author details}

${ }^{1}$ Department of Environmental Sciences, Jahangirnagar University, Dhaka 1342, Bangladesh. ${ }^{2}$ Department of Environmental Science and Disaster Management, Noakhali Science and Technology University, Sonapur 3814, Bangladesh. ${ }^{3}$ Institute of Surface Earth System Science, Tianjin University, Tianjin, China.

\section{Acknowledgements}

Authors are grateful to the regional laboratory of Soil Resource Development Institute (SRDI), Noakhali; for the instrumental and laboratory support. Authors are also thankful to the anonymous reviewers for their valuable suggestions to improve the manuscript.

\section{Author's information}

SMDI: Research student at Department of Environmental Sciences, Jahangirnagar University, Bangladesh. He completed B.Sc. (Hon's) and MS in Environmental Sciences from Jahangirnagar University in 2012 and 2013 respectively. His interested areas of research are Coastal Crisis and Management, Hydrology, and Soil Science.

MAHB: Professor and Head of the Department of Environmental Sciences, Jahangirnagar University, Bangladesh. He attended his graduation and master's program in Geological Sciences from Jahangirnagar University, and Ph.D. from Okayama University, Japan. Throughout his career he achieves the 'William Greenwood Award 1999' by Association of Geoscientists for International Development, Brazil; 'Geomorphologist Award 2009' by the International Association of Geomorphologists and 'BAS-TWAS Young Scientists Prize and Gold Medal 2014' by Bangladesh Academy of Science (BAS) and The World Academy of Science (TWAS), Italy. His area of research is on Environmental Geochemistry, Soil Science, Environmental Pollution, Remote Sensing and GIS, Disaster management, Hydromorphology and Climate Change.

MM: Assistant professor in the Department of Environmental Science and Disaster Management, Noakhali Science and Technology University, Bangladesh. He is now perusing Ph.D. at Institute of Surface Earth System Science, Tianjin University, China. He is expert on Environmental Science, Water and Soil Science.

MHA and SRM: Masters student of the Department of Environmental Science and Disaster Management, Noakhali Science and Technology University, Bangladesh. The life purpose of them is to fight against environmental degradation in Bangladesh through sustainable natural resources management.

\section{Competing interests}

The authors declare that they have no competing of interests.

\section{Availability of data and materials}

Data was generated by author's own attempt by field sampling and laboratory analysis.

\section{Consent for publication}

All authors read the manuscript and agree for publication. 


\section{Ethics approval and participant consent}

Authors declare that, this manuscript is not published or consider for publication elsewhere.

\section{Publisher's Note}

Springer Nature remains neutral with regard to jurisdictional claims in published maps and institutional affiliations.

Received: 6 September 2016 Accepted: 29 May 2017

Published online: 13 June 2017

\section{References}

Arshad MA, Coen GM (1992) Characterization of soil quality: physical and chemical criteria. Am J Altern Agric 7:25-31

Bangladesh Bureau of Statistics (BBS) (2011) Noakhali district statistics. Govt. of the People's Republic of Bangladesh, Dhaka

Banglapedia (2016) Banglapedia, National Encyclopedia of Bangladesh. http:// en.banglapedia.org/index.php?title=Noakhali_District. Accessed 30 Aug 2016.

Black CA, Evans DD, White JL, Ensminger LE, Clark FE, Dinauer RC (1965) Methods of soil analysis. Am Soc Agron Monogr. No. 9, Wisconsin, Madison, p 1572

Brady NC, Weil RR (2005) Nature and properties of soil. Edn 2.0. Pearson Publications, Singapore, p 122,214-215,251,387-388,459,521-522,872-873

Bray RH, Kurtz LT (1945) Determination of total, organic, and available forms of phosphorus in soils. Soil Sci 59:39-45

Brejda JJ, Moorman TB (2001) Identification and interpretation of regional soil quality factors for the Central High Plains of the Midwestern USA. In: Sustaining the global farm-selected papers from the 10th International Soil Conservation Organization Meeting (ISCO99)

Chitra GA, Muraleedharan VR, Swaminathan T, Veeraraghavan D (2006) Use of pesticides and its impact on health of farmers in South India. Int J Occup Environ Health 12:228-233

Department of Agriculture Extension-Agriculture Information Services (DAE-AIS) (2013) Agricultural Statistics, Policy and Planning Support Unit, Ministry of Agriculture. Government of the People's Republic of Bangladesh, Dhaka

Doran JW, Parkin TB (1994) Defining and assessing soil quality. In: Doran JW et al (eds) Defining soil quality for a sustainable environment. Soil Science Society of America Special Publication, Madison, pp 3-21

Fox RL, Olson RA, Rhoades HF (1964) Evaluating the sulfur status of soils by plants and soil tests. Soil Sci Soc Am J 28:243-246

Franzlubbers AJ, Haney RL (2006) Assessing soil quality in organic agriculture. Crit Issue Rep 2:4

FRG (2012) Fertilizer recommendation guide, Bangladesh Agricultural Research Council (BARC), Farmgate, Dhaka, p 274

Gong L, Ran Q, He G, Tiyip T (2015) A soil quality assessment under different land use types in Keriya river basin, Southern Xinjiang, China. Soil Tillage Res 146:223-229. doi:10.1016/j.still.2014.11.001

Grisso R, Alley M, Holshouser D, Thomason W (2009) Precision farming tools: soil electrical conductivity. Report produced by Virginia Cooperative Extension. Publication 442-508

Gugino BK, Idowu OJ, Schindelbeck RR, van Es HM, Wolfe DW, Moebius-Clune BN, Thies JE, Abawi GS (2009) Cornell soil health assessment training manual. Edn. 2.0. Cornell University Publisher. ISBN 0-9676507-4-7. http:// soilhealth.cals.cornell.edu, p 2-5

Gupta PK (2000) Methods in environmental analysis: water, soil and air. Agrobios Publication, India, pp 151-154

Hassan AA, Jahiruddin M, Samsun N, Sultana R, Nazmul H, Sattar A (2012) Fertilizer recommendation guide-2012. Bangladesh Agricultural Research Council, Dhaka, p 12,251-12,260

Idowu OJ, van Es HM, Abawi GS, Wolfe DW, Ball II, Gugino BK, Moebius BN, Schindelbeck RR, Bilgili AV (2008) Farmer-oriented assessment of soil quality using field, laboratory, and VNIR spectroscopy methods. Plant Soil 307:243-253. doi:10.1007/s11104-007-9521-0

Islam SMD, Bhuiyan MAH (2016) Impact scenarios of shrimp farming in coastal region of Bangladesh: an approach of an ecological model for sustainable management. Aquac Int 24(4):1163-1190. doi:10.1007/ s10499-016-9978-Z
Islam SMD, Bhuiyan MAH, Ramanathan AL (2015) Climate change impacts and vulnerability assessment in coastal region of Bangladesh: a case study on Shyamnagar upazila of Satkhira District. J Clim Chang 1(1-2):37-45. doi:10.3233/JCC-150003

Jackson ML (1962) Soil chemical analysis. Prentice Hall Inc., Englewood Cliffs, New York

Karlen DL, Mausbach MJ, Doran JW, Cline RG, Harris RE, Schuman GE (1997) Soil quality: a concept, definition, and framework for evaluation. Soil Sci Society Am J 61(1):4-10

Karlen DL, Rosek MJ, Gardner JC, Allan DL, Alms MJ, Bezdicek DF, Flock MD, Huggins R, Miller BS, Staben ML (1999) Conservation reserve program effects on soil quality indicators. J Soil Water Conserv 54:439-444

Khan TF, Ullah MW, Huq SMI (2015) Assessment of vulnerability in agricultural sector in disaster prone areas of Bangladesh. Bangladesh J Sci Res 28(2):91-101

Kibble-white MG, Ritz K, Swift MJ (2008) Soil health in agricultural systems. Philos Trans R Soc B 363:685-701. doi:10.1098/rstb.2007.2178

Kinyangi J (2007) Soil health and soil quality: a review. Draft publication. Available at: http://worldaginfo.org/files/Soil\%20Health\%20Review.pdf. Accessed 15 Feb 2016

Lagomarsino A, Moscatelli MC, Tizio AD, Mancinelli R, Grego S, Marinari S (2009) Soil biological indicators as a tool to assess the short-term impact of agricultural management on changes in organic $C$ in a Mediterranean environment. Ecol Indic 9:518-527

Lobry de Bryun LA, Abbey JA (2003) Characterization of farmers' soil sense and the implications for on farm monitoring of soil health. Aust J Exp Agric 43(3):285-305

Magdoff F, Harold VE (2009) Building Soils for Better Crops, 3rd edn. Sustainable Agriculture Research and Education (SARE) program, funding from the National Institute of Food and Agriculture, US Department of Agriculture, p 3-11

Miah MMU (2010) Assessing long-term impacts of vulnerabilities on crop production due to climate change in the coastal areas of Bangladesh. Bangladesh Center for Advanced Studies (BCAS), Dhaka

Nautiyal S, Rao KS, Kaechele H, Zander P (2010) Conceptual model development for landscape management in the mountains of the Indian Himalayan region: an approach for sustainable socio-ecological development. Landsc Online 18:1-19. doi:10.3097/LO.2010018

Northern Rivers Soil Health Card (NRSHC) (2002) NSW Department of Agriculture publications available in Wollongbar Agricultural Institute, Bruxner Highway, Wollongbar, NSW, pp 3-11. Available at: http://www.dpi.nsw. gov.au/ data/assets/pdf file/0007/168703/northern-rivers-soil-healthcard.pdf. Accessed 2 Apr 2017

Northern Rivers Soil Health Card-Perennial Horticulture (NRSHCPH) (2010) Department of Agriculture publications, Wollongbar Agricultural Institute, Bruxner Highway, Wollongbar, NSW, p 9

Page AL, Miller RH and Keeney DR (1982) Methods of soil analysis: part 2, chemical and microbiological properties. Agronomy series no. 9, American Society of Agronomy, Madison

Palouse and Nezperce-Prairies Soil Quality Card Guide (PNSQCG) (2004) Oregon State University Extension Service Publication, Lewiston, p 3-24

Petersen M (2013) Rosmarinic acid: new aspects. Phytochem Rev 12:207-227

Pettit RE (2006) The Wonderful World of Humus and Carbon. And Pimentel D Hepperly P, Hanson J, Douds D, Seidel R. 2005. Environmental, energetic and economic comparisons of organic and conventional farming systems. Bioscience, p 55, 573-582

Piper CS (1950) Soil and plant analysis. The University of Adelaide Press, Adelaide, p 368

Rahman MATMT, Aktar Z, Mondal MK, Ahmed T (2012) Environmental friendly agricultural practice in the southwestern coastal zone of Bangladesh to adapt with climate change. Int J Innov Res Dev 1(9):33-44

Raiesi F, Kabiri V (2016) Identification of soil quality indicators for assessing the effect of different tillage practices through a soil quality index in a semi-arid environment. Ecol Indic 71:198-207. doi:10.1016/j. ecolind.2016.06.061

Romaniuk R, Giuffré L, Costantini A, Bartoloni N, Nannipieri P (2014) A comparison of indexing methods to evaluate quality of horticultural soils. Part II. Sensitivity of soil microbiological indicators. Soil Res 52:409-418. doi:10.1071/SR12273 
Romig DE, Garlynd MJ, Harris RF (1996) Farmer-based assessment of soil quality: a soil health scorecard. In: Doran JW, Jones AJ (eds) Methods for assessing soil quality, vol 49. Soil Science Society of America Special Publication, Soil Science Society of America, Madison, pp 39-60

Sangral C (2015) Changes in cropping pattern and crop diversification in Jammu and Kashmir. IOSR J Humanit Soc Sci 20(4):7-9

Sarrantonio M, Doran JW, Liebig MA, Halvorson JJ (1996) On-farm assessment of soil quality and health. In: Doran JW, Jones AJ (eds) Methods for assessing soil quality, vol 49. Soil Science Society of America Special Publication, Soil Science Society of America, Madison, pp 83-105

Schumacher BA (2002) Methods for the determination of total organic carbon in soils and sediments. United States Environmental Protection Agency (USEPA) Environmental Sciences Division National Exposure Research Laboratory, p 2

Smith JL and Doran JW (1996) Measurement and use of pH and electrical conductivity for soil quality analysis. In: Doran JW, Jones AJ (eds) Methods for assessing soil quality, No. 49. SSSA Spec. Publ, Madison, p 169-186

Soil Quality Card Design Guide (SQCDG) (1999) United State Department of Agriculture (USDA), Natural Resource Conservation Service (NRCS), Soil Quality Institute (SQI), pp 7-8. Available at: https://www.nrcs.usda.gov/ Internet/FSE_DOCUMENTS/nrcs142p2_053165.pdf. Accessed 24 Oct 2016
Soil Quality Test Kit Guide (SQTKG) (1999) Soil Quality Institute, United States Department of Agriculture. Available at: http://www.nrcs.usda.gov/ Internet/FSE_DOCUMENTS/stelprdb1044790.pdf

USDA-NRCS (1998) Soil Quality Test Kit Guide. Section 1. Test procedures, and Section 2. Background and interpretive guide for individual tests. USDANRCS, Soil Quality Institute, Ames. http://www.statlab.iastate.edu

Vasu D, Singh SK, Ray SK, Duraisami VP, Tiwary P, Chandran P, Nimkar AM, Anantwar SG (2016) Soil quality index (SQI) as a tool to evaluate crop productivity in semi-arid Deccan plateau, India. Geoderma 282:70-79. doi:10.1016/j.geoderma.2016.07.010

Walkley A, Black IA (1934) An examination of the Degtjareff method for determining organic carbon in soils: effect of variations in digestion conditions and of inorganic soil constituents. Soil Sci 63:251-263

Walter G, Wander MM, Bollero GA (1997) A farmer-centered approach to developing information for soil resource management: the Illinois soil quality initiative. Am J Altern Agric 12:64-72

Wander M (2004) Soil organic matter fractions and their relevance to soil function. In: Magdoff F, Weil RR (eds) Soil organic matter in sustainable agriculture. CRC Press, New York

Wang X, Gong Z (1998) Assessment and analysis of soil quality changes after eleven years of reclamation in subtropical China. Geoderma 81:339-355

\section{Submit your manuscript to a SpringerOpen ${ }^{\odot}$ journal and benefit from:}

- Convenient online submission

- Rigorous peer review

- Open access: articles freely available online

- High visibility within the field

- Retaining the copyright to your article

Submit your next manuscript at $\boldsymbol{\nabla}$ springeropen.com 